\title{
Poltekita: Jurnal Pengabdian Masyarakat
}

Volume 2 | Nomor 1 | Januari 2021

e-ISSN: 2722-5798 \& p-ISSN: 2722-5801

http://jurnal.poltekkespalu.ac.id/PJPM/

\section{Trainning of Fasilitator Bagi Kader Kesehatan Program Penyakit Tidak Menular dalam Pencegahan dan Pengendalian Potensi Stroke}

\author{
Abdul Rivai Saleh Dunggio*, Christy Natalia Magdalena Hitijahubessy, Sri Eny \\ Setyowati \\ Poltekkes Kemenkes Maluku, Jurusan Keperawatan, \\ *Email korespondensi : rivaidunggio2016@gmail.com
}

DOI: 10.33860/pjpm.v2i1.357

History Artikel

Received: 01-12-2020

Accepted: 01-02-2021

Published: 01-02-2021

Kata kunci:

Hipertensi; Pengetahuan; Kader;

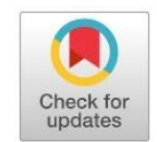

Keywords:

Hypertension; Knowledge; Cadre

\begin{abstract}
ABSTRAK
Di kota Ambon penyakit tidak menular selama 3 tahun terakhir ini terjadi kecenderungan peningkatan kasus penyakit tidak menular terutama penyakit tekanan darah tinggi. RW 08 Desa Batu Merah Kota Ambon belum mempunyai kader penyakit tidak menular sedangkan pada RT 02/RW 08 ditemukan pasien stoke. Tujuan pengabdian masyarakat adalah memberikan pelatihan dengan meningkatkan pengetahuan dan keterampilan kader dalam upaya untuk mengendalikan dan mencegah potensi stroke. Kegiatan ini dilakukan dengan metode ceramah dan pemberian leaflet tentang hipertensi dan simulasi tentang cara mengukur tekanan darah. Karakteristik peserta yang mengikuti kegiatan ini sebanyak 13 orang. Hasil yang diperoleh bahwa peserta terbanyak laki-laki 8 orang (62\%) dengan kisaran umur 26-35 sebanyak 7 orang (53\%) dan berpendidikan SMA 12 orang (92\%). Pengetahuan peserta berada pada tingkat baik 10 orang $(77 \%)$. Sedangkan kompetensi kader pada tahap pengujian pertama 2 orang (15\%) kompeten dan tahap kedua 10 orang (77\%) kompeten. Kesimpulannya bahwa terjadi peningkatan pengetahuan dan keterampiran kader setelah dilakukan pelatihan.
\end{abstract}

\begin{abstract}
In the city of Ambon, non-communicable diseases during the last 3 years there has been a tendency of increasing cases of non-communicable diseases, especially high blood pressure. RW 08 Batu Merah Village, Ambon City does not have any non-communicable disease cadres, while RT 02 / RW 08 found stoke patients. The aim of community service is to provide training by increasing the knowledge and skills of cadres in an effort to control and prevent potential stroke. This activity is carried out by lecturing methods and giving leaflets about hypertension and simulations on how to measure blood pressure. The characteristics of the participants who took part in this activity were 13 people. The results showed that most of the participants were male, $8(62 \%)$ with an age range of 26-35 as many as 7 people (53\%) and 12 people with high school education (92\%). The knowledge of the participants was at a good level of 10 people $(77 \%)$. While the competence of cadres in the first testing stage 2 people (15\%) were competent and the second stage 10 people $(77 \%)$ were competent. The conclusion was that there was an increase in cadres' knowledge and skills after training.
\end{abstract}




\section{PENDAHULUAN}

Hipertensi adalah penyebab utama stroke, penyakit jantung dan gagal ginjal. Hipertensi primer terjadi sebesar $90-95 \%$ kasus dan cenderung bertambah seiring dengan waktu. Faktor resiko meliputi obesitas, stres, gaya hidup santai dan merokok (Robinson \& Saputra, 2014). Hipertensi merupakan penyebab kematian nomor satu di dunia dan hipertensi menjadi penyebab kematian nomor tiga setelah stroke dan tuberculosis yaitu $6,7 \%$ kematian dari semua umur di Indonesia. Di banyak negara saat ini, prevalensi hipertensi meningkat sejalan dengan perubahan gaya hidup seperti merokok, obesitas, inaktifitas fisik dan stres psikososial. Hipertensi sudah menjadi masalah kesehatan masyarakat (public health problem) dan akan menjadi masalah yang lebih besar jika tidak ditanggulangi sejak dini (Natalia et al., 2015 ).

Hipertensi diperkirakan menjadi 1,15 milyar kasus pada tahun 2025 atau sekitar 29\% dari total penduduk dunia menderita hipertensi dimana 333 juta berada di Negara maju dan 639 juta sisanya berada dinegara berkembang termasuk Indonesia. Hipertensi juga menempati peringkat 2 dari 10 penyakit terbanyak pada pasien rawat jalan dirumah sakit di Indonesia dengan penderita lebih banyak wanita $(30 \%)$ dan pria (29\%) sekitar $80 \%$ kenaikan kasus hipertensi terjadi terutama dinegara berkembang (Yogiantoro, 2014).

Hampir 1 milyar orang diseluruh dunia memiliki tekanan darah tinggi. Hipertensi adalah salah satu penyebab utama kematian dini diseluruh dunia. Di tahun 2020 sekitar 1,56 milyar orang dewasa akan hidup dengan hipertensi. Hipertensi membunuh hampir 1,5 juta orang setiap tahunnya di kawasan Asia Timur-Selatan. Sekitar sepertiga dari orang dewasa di Asia Timur-Selatan menderita hipertensi (Kementerian Kesehatan R.I., 2019).

Peningkatan tekanan darah yang berlangsung dalam jangka waktu lama (persisten) dapat menimbulkan kerusakan pada ginjal (gagal ginjal), jantung (penyakit jantung koroner) dan otak (menyebabkan stroke) bila tidak dideteksi secara dini dan mendapat pengobatan yang memadai. Penyakit hipertensi mencetuskan timbulnya plak aterosklerotik di arteri serebral dan arteriol yang dapat menyebabkan oklusi arteri, cedera iskemik dan stroke sebagai komplikasi jangka panjang (Yonata \& Pratama, 2016).

Hipertensi adalah keadaan peningkatan tekanan darah yang akan member gejala lanjut kesuatu organ target seperti stroke (untuk otak), penyakit jantung koroner (untuk pembuluh darah jantung) dan hipertropi ventrikel kanan untuk (untuk otot jantung). Proses degenerative system sirkulasi dimulai dengan atherosclerosis, yakni gangguan struktur anatomi pembuluh darah perifer yang berlanjut dengan kekakuan pembuluh darah/arteri. Kekakuan dan kelambanan aliran darah menyebabkan beban jantung bertambah berat yang akhirnya dikompensasi dengan peningkatan tekanan darah dalam system sirkulasi. Peningkatan tekanan darah dengan target organ di otak berupa stroke, sehingga hipertensi menjadi penyebab utama stroke yang membawa kematian yang tinggi (Bustan, 2015).

Penentuan batasan hipertensi ini sangat penting karena perubahan tingginya hipertensi sangat mempengaruhi perRijalingan prevalensinya dalam populasi. Keadaan ini juga berkaitan dengan pentingnya definisi operasional dalam penelitian, yakni berkaitan dengan titik potong (cut-off point) dari pengelompokan hipertensi (Bustan, 2015).

Tahapan awal pasien kebanyakan tidak memiliki keluhan. Keadaan simtomatik maka pasien biasanya meningkatnya tekanan darah disertai 
berdebar-debar, rasa melayang (dizzy) dan impoten. Hipertensi vaskuler terasa tubuh cepat untuk merasakan capek, sesak nafas, sakit pada bagian dada, bengkak pada kedua kaki atau perut (Sutarno et al., 2019). Gejala yang muncul sakit kepala, perdarahan pada hidung, pusing, wajah kemerahan dan kelelahan yang bisa terjadi saat orang menderita hipertensi (Irianto, 2014).

Berdasarkan laporan hasil riset kesehatan dasar (Riskesdas) Indonesia tahun 2018 bahwa prevalensi hipertensi di Indonesia mencapai 34,11 \% sedangkan prevalensi hipertensi di provinsi Maluku mencapai 28,96\%. Jika dilihat dari karakteristik jenis kelamin bahwa perempuan 36,85 \% dan laki-laki 31,34\%. Prevalensi hipertensi berdasarkan tempat tinggal perkotaan $34,43 \%$ dan Perdesaan $33,72 \%$. Dan jika dilihat dari proporsi mengukur tekanan darah ternyata pasien hipertensi di Indonesia yang tidak mengukur tekanan darah sebesar $41.0 \%$ dan di propinsi Maluku sebesar $43,5 \%$. Proporsi pasien yang tidak mengukur tekanan darah ini lebih banyak terjadi didaerah perdesaan dibandingkan di perkotaan yaitu perdesaan $44.00 \%$ dan perkotaan 38,2\% (Kementerian Kesehatan $\mathrm{RI}, 2018)$

Di Indonesia kejadian stroke mencapai 10,9\% dan di provinsi Maluku sebesar $9,0 \%$. Prevalensi tertinggi adalah pasien hipertensi yang tidak bekerja sebesar 21,8 $\%$ dan tidak/belum pernah sekolah sebesar $21,2 \%$, dan sebesar $8,8 \%$ pasien hipertensi yang mengalami stroke ini tinggal di daerah perdesaan (Kementerian Kesehatan RI, 2018).

Insiden penyakit tidak menular semakin hari semakin meningkat.Jumlahnya semakin tinggi melebihi insiden penyakit infeksi/menular.Peningkatan ini disebabkan beberapa hal, diantaranya perubahan pola hidup dan konsumsi masyarakat.Pola hidup sendetarian yang serba instan, kurang bergerak, dan mengkonsumsi makanan berlemak dan tinggi kalori menjadi faktor predisposisi yang kuat. Penyakit tidak menular bisa berupa penyakit jantung dan pembuluh darah, penyakit DM, stroke dan kanker atau tumor dan selama 3 tahun terakhir ini terjadi kecenderungan peningkatan kasus penyakit tidak menular terutama penyakit tekanan darah tinggi (Dinkes Kota Ambon, 2015).

Masyarakat RW 08 Desa Batu Merah yang terdiri dari 5 RT merupakan penduduk yang berada dikota Ambon. Berdasarkan studi pendahuluan didapatkan bahwa RW 08 yang berada dibawah wilayah kerja Puskesmas Rijali dan mempunyai Puskesmas Pembantu (Pustu) namun belum ada kader penyakit tidak menular yang dibentuk dari masyarakat. Tahun 2018 pada RT 002 ditemukan salah satu pasien hipertensi mengalami stroke.

\section{METODE PELAKSANAAN}

Kegaiatan pengabdian kepada masyarakat dilaksanakan di RW 08 Desa Batu Merah pada 24 Oktober 2020, Sasarannya adalah perwakilan dari warga masyarakat dari 5 RT yang ada di RW 08 yang berjumlah 13 orang. Tahapan kegiatan diawali dengan perekrutan anggoata masyarakat yang menjadi kader melalui koordinasi dengan ketua RW dan Ketua RT. Pelaksanaan pemberian materi dengan ceramah dan pemberian leaflet dan pemberian materi cara mengukur tekanan darah dengan melalui demonstrasi dan simulasi. Kemudian diakhir kegiatan dilakukan evaluasi dengan menggunakan uji tulis dan uji praktek.

\section{HASIL DAN PEMBAHASAN}

Setelah pelalui proses perekrutan kader, maka dilakukan pendampingan berupa pemberian materi tentang pencegahan penyakit menular dan pengendalian 
stroke (gambar 1). Berhubung kegiatan ini dilaksanakan pada masa pandemik COVID-19 maka pengaturan lokasi kegiatan menerapkan protokol kesehatan yang ketat dimana peserta menggunakan masker dan menjaga jarak (gambar 2).

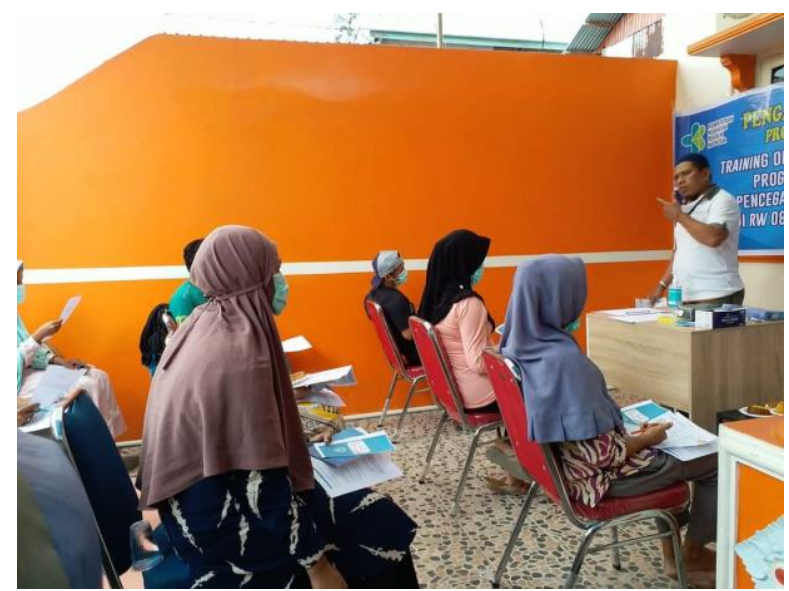

Gambar 1. Penyampaian materi tentang pencegahan penyakit menular dan pengendalian stroke

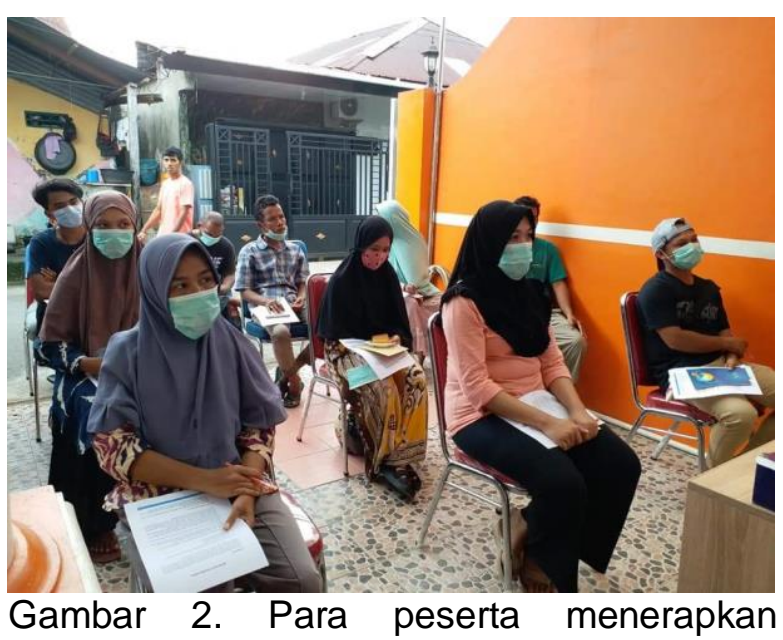

protokol kesehatan

Hasil pengumpulan data yang dilakukan saat pengabdian masyarakat di RW 08 Desa Batu Merah Kecamatan Sirimua Kota Ambon, bahwa karakteristik kader yang mengikuti kegiatan seperti terlihat pada tabel 1 menunjukan sebagian besar umur kader hipertemsi yang mengikuti kegiatan berada pada umur 26-35 tahun sebanyak 7 orang (53\%) dari 16 orang, yang mengikuti kegiatan mayoritas laki-laki yaitu berjumlah 8 orang (62\%) dari 13 orang kader dan sebagian besar adalah berpendidikan SMA yaitu 12 orang (92\%). Hasil pengukuran pengetahuan kader hipertensi setelah diberikan materi tentang hipertensi dan prosedur mendeteksi hipertensi terbanyak pada tingkatan pengetahuan yang baik yaitu 10 orang $(77 \%)$ dari jumlah 13 orang kader hipertensi

Tabel 1 Karakteristik Kader Hipertensi

\begin{tabular}{lcc}
\hline Karakteristik Peserta & Jumlah & Persentase \\
\hline Umur & & \\
$\quad 17-25$ & 5 & 39 \\
$26-35$ & 7 & 53 \\
$\quad 36-45$ & 1 & 8 \\
Jenis Kelamin & & \\
$\quad$ Laki-laki & 8 & 62 \\
$\quad$ Perempuan & 5 & 38 \\
Pendidikan & & \\
$\quad$ SD & 1 & 8 \\
$\quad$ SMA & 12 & 92 \\
Pengetahuan & & \\
$\quad$ Baik (76-100\%) & 10 & 77 \\
$\quad$ Cukup (56-75) & 3 & 23 \\
\hline
\end{tabular}


Pada kegiatan ini juga, kader dilatih dalam mengukur tekanan darah, seperti terlihat pada gambar 3

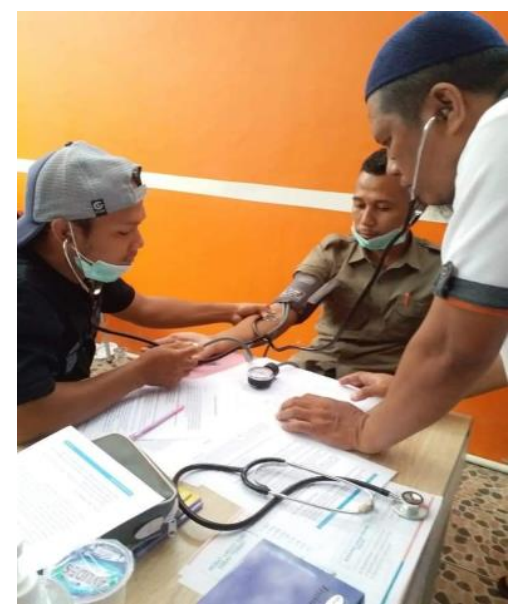

Gambar 3. Kader dilatih mengukur tekanan darah

Hasil pengumpulan data yang dilakukan saat pengabdian masyarakat di RW 08 Desa Batu Merah Kecamatan Sirimua Kota Ambon, bahwa kompetensi kader dalam mengukur tekanan darah seperti terlihat pada tabel 2 berikut ini, menunjukkan bahwa pengukuran kader atas kemampuan mereka dalam mengukur tekanan darah, hanya 2 orang $(15 \%)$ dari 13 orang kader yang kompeten. Setelah dilakukan pendampingan lagi, maka jumlah kader yang mampu (kompeten) dalam mengukur tekanan darah menjadi 10 orang $(77 \%)$. Sedangkan yang sisa berjumlah 3 orang tidak kompeten sampai selesai kegiatan. Namun 3 orang kader ini diberi kesempatan untuk belajar pada hari-hari berikutnya.

Tabel 2 Distribusi Kompetensi Kader Hipertensi Dalam Mengukur Tekanan Darah

\begin{tabular}{lcccc}
\hline \multirow{2}{*}{ Penilaian Kader } & \multicolumn{4}{c}{ Pengukuran } \\
\cline { 2 - 5 } & \multicolumn{2}{c}{ Pertama } & \multicolumn{2}{c}{ Kedua } \\
\cline { 2 - 5 } & $\mathbf{n}$ & $\%$ & $\mathbf{n}$ & $\%$ \\
\hline Kompeten & 2 & 15 & 10 & 77 \\
Tidak Kompoten & 11 & 85 & 3 & 23 \\
\hline Total & 13 & 100 & 13 & 100 \\
\hline
\end{tabular}

Hasil pengabdian masyarakat (tabel 1) dalam pembentuk pelatihan menunjukkan pengetahuan kader hipertensi setelah diberikan materi tentang hipertensi dan prosedur mendeteksi hipertensi terbanyak pada tingkatan pengetahuan yang baik yaitu 10 orang $(77 \%)$ dari jumlah 13 orang kader hipertensi. Hal ini sejalan dengan hasil yang didapatkan oleh Wahyuni et al., (2019), Setyowati et al., (2019) dan Wahyuni \& Silvitasari (2018) bahwa terjadi peneningkatan pengetahuan kader tentang materi hipertensi dan peningkatan ketrampilan kader dalam melakukan pengukuran tekanan darah setelah dilakukan pelatihan.

Pelatihan ini dilakukan bagi warga masyarakat yang belum mendapatkan pelatihan tentang materi hipertensi dan ketrampilan mengukur tekanan darah, namun demikian setelah kader mengikuti pelatihan menunjukkan peningkatan pengetahuan dan keterampilan yang baik. Hal ini sesuai dengan hasil penelitian yang dilakukan 
oleh Wirawati \& Prasetyorini (2016) pada kader yang belum mendapatkan pelatihan menunjukkan bahwa setelah mengikuti pelatihan terjadi peningkatan ketrampilan.

Menurut Arikunto (2013), bahwa pengukuran tingkat pengetahuan dapat dikatagorikan menjadi tiga yaitu: 1) Pengetahuan baik bila responden dapat menjawab 76-100\% dengan benar dari total jawaban pertanyaan; 2) Pengetahuan cukup bila responden dapat menjawab 56-75\% dengan benar dari total jawaban pertanyaan; 3) Pengetahuan kurang bila responden dapat menjawab $<56 \%$ dengan benar dari total jawaban pertanyaan

Peningkatan pengetahuan dan ketrampilan kader setelah mengikuti pelatihan juga ditunjang dengan pendidikan formal yang dimiliki kader sebagaimana pendidikan yang dimiliki kader sebagian besar berpendidikan terakhir sekolah menengah atas. Hasil penelitian Yasin (2004) menunjukkan bahwa jika pendidikan meningkat maka pengetahuannya meningkat. Artinya bahwa makin tinggi pendidikan seseorang maka akan memudahkan dalam menerima dan memahami informasi yang diterimanya. Hal ini juga diungkapkan oleh (Verawati, Ratih Sari Wardani, 2015) bahwa ada hubungan antara tingkat pendidikan dengan tingkat pengetahuan yang dapat diartikan pula semakin tinggi pendidikan maka semakin tinggi pengetahuan.

Jika pelatihan dilakukan pada kader yang sudah memiliki tingkat pendidikan yang tinggi, maka akan memudahkan dalam pemberikan informasi dan penerimaan informasi. Sebagaimana hasil penelitian Gyamfi et al., (2017) yang dilakukan pada perawat menunjukkan bahwa pelatihan singkat sekalipun dalam manajemen dan pengendalian hipertensi dapat memberikan manfaat kesehatan masyarakat yang besar kemungkinan besar akan dicapai.

\section{KESIMPULAN}

Setelah dilakukan kegiatan pengabdian kepada masyarakat dalam bentuk Program Kemitraan Masyarakat bagi masyarakat kader hipertensi maka dapat disimpulkan bahwa: Pengetahuan kader hipertensi mengalami peningkatan melalui penyuluhan kesehatan dalam bentuk ceramah dan pembagian leaflet dan Ketrampilan kader untuk melakukan pengukuran tekanan darah mengalami peningkatan setelah dilakukan pendampingan. Untuk mendapatkan hasil yang efektif dan berkelanjutan tentang pengetahuan dan ketrampilan kader, maka harus dilakukan monitoring dan evaluasi dalam bentuk praktek langsung ke masyarakat sehingga tujuan pengabdian kepada masyarakat dalam rangka pencegahan dan pengendalian stroke dapat tercapai.

\section{DAFTAR PUSTAKA}

Arikunto, S. (2013). Prosedur Penelitian Suatu Pendekatan Praktik. Rineka Cipta.

Bustan, M. N. (2015). Manajemen Pengendalian Penyakit Tidak Menular. Rineka Cipta.

Dinkes Kota Ambon. (2015). Profil Kesehatan Kota Ambon 2015. Dinkes Kota Ambon.

Gyamfi, J., Plange-Rhule, J., Iwelunmor, J., Lee, D., Blackstone, S. R., Mitchell, A., Ntim, M., Apusiga, K., Tayo, B., Yeboah-Awudzi, K., Cooper, R., \& Ogedegbe, G. (2017). Training nurses in task-shifting strategies for the management and control of hypertension in Ghana: a mixed-methods study. BMC Health Services Research, 17(1), 1-9. https://doi.org/10.1186/s12913-017-2026-5

Irianto, K. (2014). Epidemiologi Penyakit Menular dan Tidak Menular Panduan Klinis. Alfabeta.

Kementerian Kesehatan RI. (2018). Laporan Hasil Riset Kesehatan Dasar (Riskesdas) Indonesia tahun 2018. In Riset Kesehatan Dasar 2018 (hal. 182-183).

Kementerian Kesehatan R.I. 2019. "Hipertensi Penyakit Paling Banyak Diidap Masyarakat." Diambil (https://www.kemkes.go.id/article/view/19051700002/hipertensi-penyakit-paling- 
banyak-diidap-masyarakat.html).

Natalia, D., Hasibuan, P., \& Hendro, H. (2015). Hubungan Obesitas dengan Kejadian Hipertensi di Kecamatan Sintang, Kalimantan Barat. CDK: Cermin Dunia Kedokteran, 42(5), 336-339. http://www.cdkjournal.com/index.php/CDK/article/view/1008/729

Robinson, J. M., \& Saputra, L. (2014). Buku Ajar Visual Nursing (Medikal Bedah) Jilid 1. Binarupa Aksara.

Setyowati, D., Tri, M., \& Swandari, K. (2019). Pelatihan Kader CERDIK Sebagai Upaya Pencegahan Dan Pengendalian Peningkatan Tekanan Darah di Dusun Tembok Desa Menganti Kabupaten Cilacap. Jurnal Pengabdian Masyarakat Al-Irsyad, I(2), 82-90.

Sutarno, Setyowati, D., \& Swandari, M. T. K. (2019). Pelatihan Kader CERDIK Sebagai Upaya Pencegahan Dan Pengendalian Peningkatan Tekanan Darah di Dusun Tembok Desa Menganti Kabupaten Cilacap. Jurnal Pengabdian Masyarakat Al-Irsyad, I(2), 8290.

Verawati, Ratih Sari Wardani, N. N. A. (2015). Hubungan Tingkat Pendidikan Dan Pengetahuan Dengan Perilaku Perawatan Vulva Hygiene Pada Wanita Di Lapas Semarang Tahun 2014. Jurnal Kebidanan, 4(2), 21-26.

Wahyuni, \& Silvitasari, I. (2018). Pelatihan Dan Pendampingan Pada Kegiatan Pengukuran Tekanan Pada Kader Posyandu Di Kalurahan Sidorejo. GEMASSIKA: Jurnal $\begin{array}{llll}\text { Pengabdian Kepada } & \text { Masyarakat, }\end{array}$ https://doi.org/10.30787/gemassika.v2i2.314

Wahyuni, W., Sri wahyuni, E., \& Silvitasari, I. (2019). Peningkatan Pengetahuan Hipertensi Dan Pelatihan Penghitungan Nadi Dan Pengukuran Tekanan Darah Pada Kader Posyandu Di Desa Sidorejo. Warta LPM, 22(1), 40-44. https://doi.org/10.23917/warta.v21i2.6708

Wirawati, M. K., \& Prasetyorini, H. (2016). Upaya Peningkatan Ketrampilan Kader Posyandu Dalam Pengukuran Tekanan Darah Melalui Pelatihan Kader. Jurnal IImu dan Teknologi Kesehatan, 7(2), 27-30.

Yasin, N. M. (2004). Pengaruh Tingkat Pendidikan Terhadap Tingkat Pengetahuan Masyarakat Tentang Pengobatan Sendiri (Selfmedication) Di Wilayah Kabupaten Sleman Jogjakarta. Jurnal Ilmiah Farmasi, 1(2).

Yogiantoro, M. (2014). Pendekatan Klinis Hipertensi. In Buku Ajar IImu Penyakit dalam Edisi ke Enam Jilid II. Interna Publishing.

Yonata, A., \& Pratama, A. S. P. (2016). Hipertensi sebagai Faktor Pencetus Terjadinya Stroke. Medical Journal of Lampung University, 5(3), 17-21. https://juke.kedokteran.unila.ac.id/index.php/majority/article/view/1030/824 